\title{
Adaptation of Collins' Revised Adult Attachment Dimensional Scale to the Chilean Context
}

\author{
Adaptação da Escala Dimensional Revisada de Apego Adulto de Collins \\ para o Contexto Chileno
}

\author{
Ana María Fernández ${ }^{*}, a$ \& Michele Dufey ${ }^{b}$ \\ ${ }^{a}$ Universidad de Santiago de Chile, Santiago, Chile $\&{ }^{b}$ Universidad Diego Portales, Santiago, Chile
}

\begin{abstract}
The Adult Attachment Revised Scale is a measure of relationship attachment that contains three dimensions: closeness, dependence and anxiety. In Study 1, the scale was translated and applied to a sample of 420 university students in order to assess reliability. In addition, the scale criterion validity was estimated through measures of self-perception and affectivity. The results of Study 1 supported the internal consistency of two dimensions of attachment, but dependence was lower than expected $(\alpha=.62)$. A confirmatory factor analysis was conducted and failed to reach a convergent fit, thus demonstrating that two of the items in dependence were considered problematic. In Study 2, difficult items in Study 1 were reworded and the new version of the scale was applied to 81 participants. The results of two subsequent CFAs showed adequate fit of the scale and increased internal consistency with this new wording $(\alpha>.73)$, which replaced the expression "depend on others" by "getting help from others", which is a better construct representation of the meaning of dependence in the context of attachment closeness. Therefore, not only did we adapt the three dimensions of the attachment scale, but also provided evidence of its validity related to locally adapted instruments.

Keywords: Attachment, close relationships, psychometrics.

Resumo

A Escala Revisada de Apego Adulto é uma medida de apego relacional com três dimensões: proximidade, dependência e ansiedade. No Estudo 1, traduzimos a escala e a aplicamos em uma amostra de 420 universitários, visando avaliar sua confiabilidade. Estimamos ainda o critério de validade da escala mediante comparação com medidas de auto-percepção e afetividade. Os resultados do Estudo 1 apoiam a consistência interna inicial de duas das dimensões do apego, porém a da dependência foi mais baixa do que o esperado $(\alpha=0,62)$. Realizamos uma análise fatorial confirmatória que não atingiu um ajuste convergente, indicando dois itens da dimensão de dependência como problemáticos. No Estudo 2, reformulamos os itens problemáticos do Estudo 1, e aplicamos a nova versão da escala em 81 participantes. Os resultados das duas AFC subsequentes mostraram um ajuste adequado da escala e um incremento da consistência interna com a nova redação $(\alpha>0,73)$, a qual substituiu a expressão "depender dos demais" por “conseguir ajuda dos demais". Dessa forma, conseguimos não só efetuar uma adaptação dos três construtos da escala, como também encontramos evidências da sua validação por meio da comparação com as outras escalas.

Palavras-chave: Apego, relacionamentos próximos, psicometria.
\end{abstract}

Ever since Bowlby's pioneering research (1979/1989) the study and assessment of attachment has been essential to understand the innate development of human close emotional bonds, from infancy and throughout adult development, and old age (Collins \& Feeney, 2013). At present, the theory and description of childhood patterns of anxiety (and recovery) after separation from the primary caretaker (Ainsworth, 1979; Verissimo et al., 2011), has been extended to the comprehension of adult affective bonding, the study of romantic attachment styles, and models of the self and others in the context of close relationships, among others (Collins \& Feeney, 2004; Ford \& Collins, 2010; Mikulincer \& Shaver, 2007; Mota \& Matos, 2009).
* Mailing address: Escuela de Psicología, Universidad de Santiago de Chile, Avenida Ecuador, 3650, tercer piso, Estación Central, Santiago, Chile. E-mail: ana. fernandez@usach.cl and mdufey@gmail.com Acknowledgements: This research was supported by an Initiation grant from Fondo Nacional de Desarrollo Científico y Tecnológico (FONDECYT, National
Science and Technology Funding) \#11110439 entitled "Sex-differences in mating: The influence of attachment, mate value and affectivity in 'romantic jealousy"' awarded to the first author.

The authors would like to thank José Antonio Muñoz, Rachel Ripardo, and Marco Varella for their contribution to language editing in Portuguese. 
Collins (1996) developed a scale assessing continuous attachment dimensions in adulthood, going beyond earlier trends deriving discrete categories equivalent to specific attachment styles (Bartholomew \& Horowitz, 1991; Hazan \& Shaver, 1987) which although different from one another are potentially related (Collins, 1996). Similarly, the Experiences in Close Relationships (ECR; Brennan \& Shaver, 1998; Fraley, Waller, \& Brennan, 2000) is a newer instrument than Collins's scale, based on empirical analysis of previously existing questionnaires which generated two distinct and also continuous attachment dimensions: anxiety and avoidance. But, although the ECR is widely used in relationships research, and is adapted to some South American countries such as Chile and Brazil (Guzmán \& Contreras, 2012; Paiva \& Figueiredo, 2010), it is a measure that does not allow targeting more specific aspects of security, like an individual's comfort with closeness or dependence in a continuous manner; since it only represents the unsecure realms of attachment. Therefore, to date, the Adult Attachment Scale (AAS, Collins \& Read, 1990) and its revised version (AASR, Collins, 1996) is a useful measure to incorporate in our local context when the aim of research is to assess adult attachment, particularly in the continuous dimensions of closeness, and comfort with depending on others, as well as anxiety in close relationships.

Similarly, research addressing romantic attachment usually incorporates other affective and cognitive measures that are related to the nature of close relationships in order to inquire the associations of adult attachment with related constructs such as self-esteem, relationship quality, cognitive beliefs about the partner, and the like (see for example Collins, Ford, Guichard, \& Allard, 2006; Feeney \& Collins, 2001). Nevertheless, we also included other variables that have been extensively studied in the social and mating literature, and that are potentially related to the dimensions of attachment in the context of adult close relationships. Mate value, reactivity to jealousy, and aggression, which are seldom assessed in association to attachment (but see Cooper, Shaver, \& Collins, 1998; Fletcher, Simpson, Thomas, \& Giles, 1999) were integrated in the investigation and adaptation of the AASR in Chile.

According to Collins and Read (1990), the attachment system is a cognitive representation of how individuals relate to others throughout their lifetime, as well as how others have responded to social interaction and close relationships with the individual (working models of the self and others). Childhood styles are similar to adult attachment: secure individuals feel loved and valued, they are comfortable with intimate relationships and can depend on others; avoidant persons are well-off free from emotional dependence on others, and do not care about whether they are accepted by others or not; preoccupied individuals want to form significant relationships with others but are worried about being rejected and unloved (Collins \& Feeney, 2010). The dimensions of attach- ment proposed by Collins and Read (1990) decompose the classical secure-unsecure categories of attachment mentioned above, according to theoretical and empirical predictions, arriving to three continuous scales. A person's comfort with close and intimate relationships (close); the individual's feeling that they can count on others, and that others would be around when in need of them (depend); the person's level of fear that others would leave or reject them (anxiety; Collins, 1996).

In the first study we review the relationships among attachment dimensions proposed by Collins and Read (1990) and other affective and relational variables (Collins, 1996; Collins, Ford, Guichard, \& Feeney, 2006; Cooper et al., 1998), replicating and adding to the hypothetical predictions about the construct validity of the AASR. We used for this purpose particular attachment related instruments and other mating variables that have already been adapted to the Chilean context. We also performed a confirmatory factor analysis (CFA) on the structure of the scale, which led us to conduct an additional confirmatory investigation with a completely new sample in Study 2.

\section{Study 1}

Adult attachment can be conceptualized as internal working models regulated by social input (Collins \& Read, 1990; Hazan \& Shaver, 1994; Shaver, Collins, \& Clark, 1996) or how individuals have come to view themselves as worthy of love and affection throughout development (model of the self), as well as how comfortable the person feels establishing close and intimate relationships (model of others). Accordingly, the interpersonal experiences that an individual has faced in other aspects of relationships serve to sustain his or her actual mental models of attachment as an adult (Hazan \& Shaver, 1994).

There are many predictions that can be drawn about the dimensions of attachment, and the way other psychological constructs would be represented in individuals holding distinct attachment patterns. "Adults enter relationships with a history of interpersonal experiences and a unique set of memories, beliefs, and expectations that shape how they think and feel about their relationships and how they behave in those relationships" (Collins, Ford, Guichard, \& Allard, 2006, p. 201).

The continuous dimensions of attachment were initially drawn-out from the classical types, and it was predicted that secure attachment would involve high scores on the close and depend dimensions, and low scores on anxiety. The anxious type was expected to be characterized by low scores on close and depend subscales, and high anxiety scores. While the avoidant type, was expected to attain low scores on all the attachment dimensions: close, depend and anxiety (Collins \& Read, 1990).

In addition to the above predictions, it was hypothesized that the components of the model of the self, portrayed in the close and depend scales, would be positively 
correlated with variables that indicate an affirmative selfperception, such as self-esteem, mate value components, positive affect and perceived relationship quality. The close and depend dimensions, on the other hand, would be expected to be inversely associated to variables indicative of negative views of the self, such as aggression, jealousy, and negative affect. And finally, the model of others portrayed in the anxiety scale, was expected to correlate in a positive way with aggression, jealousy, and negative affect (see Collins, Ford, Guichard, \& Allard, 2006; Collins \& Read, 1990; Cooper et al., 1998).

\section{Method}

\section{Sample}

A total of 452 participants completed the attachment scale, but we eliminated the responses of 28 participants that did not answer all the items in the scale: one participant that did not report demographic data, and three participants under the age of 18. Therefore our sample size for Study 1 was $N=420$ (27.1\% men), with an average age of 28.3 years $(S D=10.59)$, and ranging from 18 to 65 years of age. In order to test the predictions between AASR subscales and the above mentioned affective variables, different subsamples completed some of the construct validity measures, which are detailed in the next subsection (see additional correlated measures on Table 1).

For the analysis of the discrete attachment categories, 34 cases were eliminated which overlapped by their score on more than one attachment style (see Collins \& Read, 1990).

\section{Instruments}

Adult Attachment Scale Revised (AASR). The AASR (Collins, 1996) was back-translated into Spanish following the criteria suggested by Triandis and Berry (1980). A bilingual collaborator with a background in Educational Sciences, translated the scale into Spanish, and then a bilingual Psychologist translated the scale back into English. A graduate student and the first author revised both versions of the scale, trying to maintain the conceptual meaning of each item and its underlying construct, and setup the Chilean version of the instrument. The dimensions of attachment were maintained in their three original scales: Close, evaluating comfort with closeness and intimacy (items 1, 6, 8, 12, 13, 17); depend, measuring reciprocal availability of others when needed $(2,5,7,14$, $16,18)$; and anxiety, evaluating the amount of worry about being left alone and unloved $(3,4,9,10,11,15)$. There are a total of 18 items, six on each dimension and they are scored on a scale from 1 to 5 (1- not at all characteristic of me, 5- very characteristic of me). Items 2, 7, 8, 12, 13, 16, 17 and 18 are reversed scored.

Rosenberg's Self-Esteem Scale (RSE). The Chilean adapted version of Rosenberg's (1965) 10 item questionnaire was used, which includes 10 statements (scored on a scale from 1- strongly disagree to 4- strongly agree) tapping into a global concept of self-esteem (Rojas-Barahona, Zegers, \& Förster, 2009). It's internal consistency for the current sample was adequate (see Table 1).

Positive Affect and Negative Affect Schedules (PANAS). Is a measure of 20 affective adjectives developed by Watson, Clark and Tellegen (1988), and adapted locally by Dufey and Fernández (2012). The adjectives are scored on a scale ranging from 1 -very little or nothing at all, to 5 - extremely, 10 of them portray positive affect (PA) and 10 of them negative affect (NA). As it can be observed on Table 1, both scales reached optimal reliability levels.

Mate Value Components. The Chilean adaptation (Fernández, Muñoz-Reyes, Dufey, Buccioni, \& Cid, in press) of the Mate Value Components (MVC; Fisher, Cox, Bennett, \& Gavric, 2008) is composed of 22 statements about different realms of mating success, sociality, resources, and parenting. Answers are given using a 7-point scale $(1=$ strongly disagree to $7=$ strongly agree $)$. For the current application the internal consistencies can be observed on Table 1.

Jealousy Reactions. The inventory created by Dijkstra, Barelds, and Groothof (2010) of jealousy evoking partner behaviors was used to assess a global score of reactivity to jealousy evoking situations. The local adapted version of the questionnaire was used (Fernández, Pavez, \& Dufey, in press). This instrument contains 42 questions asking participants "how jealous would you feel if..." the partner engages in various real-live and Web-based interactions with third persons of the opposite sex. The responses are assessed on a five-point scale ranging from $1=$ not jealous to $5=$ very jealous (see Table 1 for the internal consistency of the current study).

Perceived Relationship Quality Components (PRQC). An abbreviated version of the PRQC (Fletcher, Simpson, $\&$ Thomas, 2000) was used in the study which was adapted to Chile by Schmitt et al. (2004). It is composed of six face valid questions about satisfaction, commitment, intimacy, trust, passion, and love. The answers are given on a scale ranging from 1 (nothing at all) to 7 (completely). It's internal consistency for the current sample was adequate (see Table 1).

Buss and Perry Aggression Questionnaire (BPAQ). Is a measure of aggression widely used internationally (Buss \& Perry, 1992) tapping into four dimensions: (a) physical aggression, (b) verbal aggression, (c) anger, and (d) hostility. It includes 29 items that are scored on a Likert type scale (1- extremely uncharacteristic of me, 5- extremely characteristic of me). It was adapted locally by Figueroa Rey, Ramírez Troncoso, and Santis Doyhamboure (2005). For the current study, verbal aggression is not included in the analysis since it reached unacceptable low levels of internal consistency (Cronbach's alfa $<.5$; see Table 1 ). 
Fernández, A. M. \& Dufey, M. (2015). Adaptation of Collins' Revised Adult Attachment Dimensional Scale to the Chilean Context.

Table 1

Correlations between AAS Subscales and other Affective Scales

\begin{tabular}{cccccccccc}
\hline & \multicolumn{1}{c}{ Other affective instruments } \\
\cline { 2 - 9 } & RSE & JReac & PA & NA & MVC & PRQC & PhA & A & H \\
\hline \multirow{2}{*}{$n$} & 66 & 354 & 138 & 136 & 386 & 168 & 36 & 36 & 36 \\
Alpha & .81 & .97 & .91 & .88 & .83 & .87 & .82 & .84 & .79 \\
Close & $.418^{* *}$ & .024 & .098 & -.055 & $.333^{* *}$ & $.234^{* *}$ & -.221 & -.114 & $-.420^{* *}$ \\
Depend & $.309^{* *}$ & -.049 & .068 & -.067 & $.185^{* *}$ & $.241^{* *}$ & $-.280^{*}$ & -.168 & $-.501^{* *}$ \\
Anxiety & $-.421^{* *}$ & $.215^{* *}$ & -.134 & .125 & $-.130^{* *}$ & -.040 & .199 & $.331^{* *}$ & $.489^{* *}$ \\
\hline
\end{tabular}

Note. RSE: Rosenberg's Self-Esteem Scale; JReac: Jealousy Reactions; PA: Positive Affect Scale of the PANAS; NA: Negative Affect Scale of the PANAS; MVC: Mate Value Components; PRQC: Perceived Relationship Quality Components; PhA: Physical Aggression subscale from the BPAQ; A: Anger subscale of the BPAQ; H: Hostility subscale from the BPAQ.

$* p<.05 ; * * p<.001$.

\section{Procedure}

All methods and procedures of this study were approved by the Ethical Committee of the first author's institution. Participation was achieved in two manners: (a) completing paper and pencil questionnaires containing an informed consent, demographic questions and all the measures; (b) through an online platform, that begun with downloading of the informed consent, completing a demographic questionnaire, followed by the attachment scale and other measures of individual differences. Participation was absolutely voluntary and without compensation.

\section{Data Analysis}

We used SPSS 20.0 to analyze the data on Study 1. Descriptive statistics on demographic and all the individual measures were estimated in frequencies and percentages for categorical data, and mean and standard deviations for the continuous measures. For the construct validity, and test-retest stability analyses, we estimated one-tailed Pearson correlation coefficients among the dimensions of the scale and the other variables. Internal consistency was estimated using Cronbach's alpha. For the CFA we used EQS 6.2. Because of non-normal distribution that likert- response items are expected to have (due to an ordinal measurement level), all analysis were run with Robust Maximun-Likelyhood methods for parameters estimation (Byrne, 2006). Multivariate LM Test analysis were simultaneously performed with CFA, in order to obtain modification indices that could orient which parameters could be freely estimated in subsequent specifications of the model, in case of a model misfit. Consequently, we considered S-B $\chi^{2}$ for non-normal distributed samples (Satorra \& Bentler, 1988), and CFI (Bentler, 1990; > .94), RMSEA (Hu \& Bentler, 1999; < .7), and the $90 \%$ C. I. robust statistics to decide model fit.

\section{Results}

\section{Reliability}

As shown in Table 2, Cronbach's alpha showed satisfactory internal consistencies for the anxiety subscale, followed by close and depend subscales. Additionally, a test-retest analysis was performed with a subsample of participants that completed the scale 60 days after the initial application $(n=30$, women $=73.3 \%)$, indicating significant and high levels of temporal stability for all subscales (see Collins \& Read, 1990 for comparable indices).

Table 2

Descriptive Statistics, Internal Consistencies, and Stability of the AASR Subscales

\begin{tabular}{lccc}
\hline & \multicolumn{3}{c}{ Attachment subscales } \\
\cline { 2 - 4 } & Close & Depend & Anxiety \\
\hline Mean $(S D)$ & $21.76(4.39)$ & $18.23(4.23)$ & $15.13(5.79)$ \\
Cronbach's Alpha & .68 & .62 & .85 \\
Test-retest $(r)$ & $.57^{*}$ & $.74^{*}$ & $.71^{*}$ \\
\hline
\end{tabular}

${ }^{*} p<.001$. 


\section{Validity}

Correlations among Attachment Dimensions. Consistent with previous work (e.g., Collins, 1996), the close and dependence dimensions were positively and moderately correlated $(r=.436 ; p<.001)$, and negative associations among anxiety and close $(r=-.280 ; p<.001)$, as well as anxiety and depend $(r=-.402 ; p<.001)$ subscales were obtained.

Similarly, as Table 3 shows, the categorical types of attachment originally derived from cluster analysis by
Collins and Read (1990), showed the predicted empirical configuration of the dimensions of attachment that underlie the AASR. Secure attachment was indicative of significantly high levels of the close and depend dimensions, and significantly low levels of anxiety, in comparison to the highest levels of anxiety attained in the anxious type. Anxious attachment differed significantly from the secure type, by its low scores on the depend dimension. And finally, the avoidant type showed the lowest intensities on all the dimensions of attachment.

Table 3

Mean Scores on the Dimensions of Attachment according to the Discrete Types Derived from the AASR

\begin{tabular}{lcccc}
\hline & \multicolumn{4}{c}{ Attachment Style } \\
\cline { 2 - 5 } AASR Dimension & Secure & Anxious & Avoidant & $F(2,325)$ \\
\hline$n$ & 221 & 67 & 40 & \\
Close & $23.7(3.23)$ & $23.7(2.88)$ & $16.7(3.65)$ & $84.35^{*}$ \\
Depend & $20.4(3.04)$ & $18.8(3.35)$ & $14.2(3.08)$ & $68.13^{*}$ \\
Anxiety & $11.3(3.17)$ & $21.6(2.48)$ & $11.9(3.43)$ & $291.07^{*}$ \\
\hline
\end{tabular}

${ }^{*} p<.001$.

Correlations among Attachment Dimensions and other Affective Variables. As the close and depend dimensions of attachment imply more self-worth, security and comfort in social situations, as well as a positive view of others and the world, we expected positive associations among close and depend subscales and: self-esteem, mate value, positive affect, and the perceived quality of relationships, whereas negative associations were predicted between those subscales and: aggression, jealousy reactivity, and negative affect. On the other hand, since the anxiety dimension is as associated with a tendency to worry of being rejected or abandoned in relationships, we hypothesized positive correlations for this subscale and jealousy reactivity, negative affect, and the affective and cognitive aspects of aggression. Finally, negative relationships between anxiety and self-esteem, positive affect, mate value, and quality of relationships were predicted. The results confirmed most of the hypothesized associations, showing positive and significant correlations among close as well as depend dimensions and: self-esteem, mate value, and quality of relationships; whereas these attachment dimensions correlated inversely with hostility. Depend was negatively associated to physical aggression, and the anxiety dimension was positively related to jealousy reactivity, anger and hostility; and it showed negative correlations with self-esteem and mate value (see Table 1).

\section{Factor Analysis}

In order to test the theoretical structure of the AASR, a CFA was performed specifying a three factor model.
Since a convergent solution was not obtained, we run again the analysis dropping items 2 and 5 of the dependence subscale (which were problematic on the first analysis). This decision was made after considering both statistical and substantive criteria: (a) the relative low alpha value of the dependence subscale; (b) the alpha value of the total subscale was improved if those items were deleted; and (c) both items contained a direct translation of "dependence" which may had led to construct imprecision. Therefore an evaluation of language adequacy of the translated items suggested that the meaning of "dependence" may have a bad connotation in the local context. The result of the second CFA showed an improved but still not a good fit of the model (S-B $\chi^{2}=292.75 ; d f=101 ; p<.001$; relative $\chi^{2}=2.89$; values below 5 are acceptable, see Schumacker $\&$ Lomax, 2004); TLI $=.89$; CFI $=.91$; RMSEA $=.067$; $90 \%$ I.C. $=.058-.076$ (see Table 4 for factor loadings).

\section{Discussion Study 1}

The AASR reached satisfactory reliability indexes, as seen in both internal consistency and test-retest analysis. Nevertheless, the test-retest sample size was much reduced in comparison to the total sample, so this is a limitation to the estimation of the temporal stability of the attachment scale. Similarly, the depend subscale had acceptable but lower alpha values, suggesting taking with caution this result in further analysis.

Regarding validity of the AASR, we first looked at the interrelations among its subscales, finding a positive 
association among the close and depend dimensions, and a negative correlation between both of them and anxiety. Secondly, the continuous subscales showed the expected configuration into the attachment types: the secure type classified individuals with high levels of close and depend, but low levels on the anxiety dimension; the anxious type reached high levels of anxiety and close, but low levels of depend; and the avoidant type characterized individuals with low levels on all the dimensions of attachment. These findings reinforce the close associations that exist among the AASR dimensions, although there are discrete differences between them, as it is consistent with previous research (Collins \& Read, 1990).

Additionally, we sought to test several hypotheses regarding construct validity of the AASR, finding that both depend as well as the close subscales were positively associated with self-esteem, mate value and quality of relationships, and negatively correlated with hostility. This convergence is not surprising as both subscales of the AASR are correlated, implying that as people tend to feel more self-worth, secure and comfortable in social situations, and have a positive view of others and the world, they also perceive themselves as more efficient and are more self-acceptant in their relationships, having a greater subjective estimation of their individual possibility to mate, as well as better quality of romantic relationships (Collins, Ford, Guichard, \& Allard, 2006). Additionally, the closer and more dependent a person is, the less he/she is prone to hostility or the tendency to have negative appraisals about others and situations, which is characteristic of the accompanying lower levels of physical aggression for the depend dimension (Collins, Ford, Guichard, \& Feeney, 2006).

The anxiety dimension was positively associated with jealousy reactivity, anger and hostility, and correlated negatively with self-esteem and mate value. This means that people that are more worried of being rejected or abandoned in relationships, are also more jealous in romantic relationships (interpreting more behaviors from their partner as potentially mistrustful), and they experience increased levels of the affective and cognitive dimensions of aggression. On the other hand, they also feel a smaller amount of self-worth, are less secure and comfortable in social situations, and have a poorer self-estimation of their individual value as partners.

However, one limitation to the evidence of validity provided by the previous analysis is the varying subsample sizes that completed the comparison instruments, going from almost half the complete sample for jealousy, affectivity and mate value, to less than a quarter of the sample answering to the self-esteem and aggression scales.

Regarding factor analysis, we failed to find a model adjustment of the AASR through a CFA even after dropping problematic items of the depend subscale (items 2 and 5), a possibility that was suggested by the low internal consistency values on the subscale. In order to keep the original conformation of the AASR, we therefore sought to revise and modify language adequacy of those problematic items, and we tested the theoretical structure of the scale in a new sample on Study 2.

\section{Study 2}

Due to reliability problems of the depend subscale which could partially explain the bad adjustment of the AASR in the CFA we run in Study 1, we generated a new version of the instrument with a modified translation of the word "dependence" on items 2 and 5. In this version of the scale, we realized that the word dependence in the Chilean context has a strong negative meaning, referring to a lack of autonomy and self-sufficiency. Consequently, the correct conjugation of the Spanish adjective "apoyarme" (getting support) was used in items 2 and 5 , to refer to dependence.

Thus, in this second study we expected to improve the construct validity of the scale modifying the language of two of the items of the depend dimension, and we expected to arrive to an acceptable fit of the Chilean version of Collins' AASR (1996).

\section{Method}

\section{Sample}

The sample of Study 2 was conformed of 89 participants $(24.7 \%$ men), with a mean age of 29.4 years $(S D=$ 8.78 , range $=18-55), 8$ subjects which had missing data were dropped off the analysis.

\section{Instruments}

We applied general demographic questions and the modified version of the AASR.

\section{Procedure}

We used an online platform following the same procedures of Study 1.

\section{Results}

\section{Reliability}

Cronbach's alpha for each subscale was .73 (Closeness), .80 (Depend), and .87 (Anxiety), indicating an improvement in the internal consistencies for all subscales and particularly for the depend dimension, which was the more problematic result as seen in Study 1.

\section{Factorial Validity}

The first CFA we ran did not show a better model adjustment than the one observed in Study 1 (S-B $\chi^{2}=$ $200.125 ; d f=132 ; p<.001 ;$ relative $\chi^{2}=1.51 ; \mathrm{TLI}=.86$; $\mathrm{CFI}=.88$; RMSEA $=.079 ; 90 \%$ I.C. $=.056-.100$ ), so we looked at modification indices that could explain this poor 
result. We identified a problematic correlation between measurement error terms of items 15 and 10, and 15 and 5 (when a zero correlation between error terms is expected), as well as a cross-loading of item 5 in factor 1 (when it was expected to only have a factor loading in factor 2), which could be accounting for the lack of CFA adequacy, but made theoretical sense if one considers the overall meaning of these items (Byrne, 2006). The adjustment indicator values of the second $\mathrm{CFA}$ improved to a marginally significant good fit of the model (S-B $\chi^{2}=170.618 ; d f$ $=130 ; p<.01$; relative $\chi^{2}=1.31$; variance adjusted $\chi^{2}=$ $39.88, d f=30, p=.10$; TLI $=.91 ; \mathrm{CFI}=.93$; RMSEA $=$ $.062 ; 90 \%$ I.C. $=.032-.085$ ), which we estimated as an acceptable adequacy of the scale in the local context (see Table 4 for factor loadings).

Table 4

Factor Loadings for the CFAs of Study 1 and 2 on Each of the Dimensions of the AASR

\begin{tabular}{|c|c|c|c|}
\hline & \multicolumn{3}{|c|}{ Attachment Style Dimension } \\
\hline Item & Close & Depend & Anxiety \\
\hline 1 & .54 .33 & & \\
\hline 2 & & .45 & \\
\hline 3 & & & .70 .73 \\
\hline 4 & & & .61 .79 \\
\hline 5 & & .16 & \\
\hline 6 & .21 .29 & & \\
\hline 7 & & .70 .77 & \\
\hline 8 & .69 .82 & & \\
\hline 9 & & & .75 .76 \\
\hline 10 & & & .67 .66 \\
\hline 11 & & & .86 .77 \\
\hline 12 & .67 .71 & & \\
\hline 13 & .47 .64 & & \\
\hline 14 & & .74 .76 & \\
\hline 15 & & & .57 .60 \\
\hline 16 & & .54 .63 & \\
\hline 17 & .55 .65 & & \\
\hline 18 & & .81 .82 & \\
\hline
\end{tabular}

Note. $N$ for Study $1=420, n$ for Study $2=89$; loadings appear on each dimension (columns): on the left for Study 1 and on the right for Study 2; items 2 and 5 are excluded on Study 1.

\section{Discussion Study 2}

The aim of Study 2 was to test the theoretical structure of the AASR, after modifying the translation of items 2 and 5, which showed to be problematic after considering both statistical (relatively low alpha values) as well as substantive (language adequacy) criteria. The first CFA showed a model misfit, and when looking at modification indices that could improve model adequacy in a new CFA, we found a correlation between error terms of items 15 ("I want to get close to people, but I worry about being hurt") and 10 ("When I show my feelings for others, I'm afraid they will not feel the same about me"), as well as item 15 and 5 ("I am comfortable depending on others"). This implies some degree of content overlapping of those items, a finding that should be considered in further studies aimed to assess model adequacy of the AASR through CFA, in a similar context. We also found a crossloading of item 5 on factor 1 , which belongs to the close subscale (when it only should load on factor 2 corresponding to the depend subscale). Since internal consistency of the depend subscale improved after revising item translation in Study 2, we can consider the possibility that, in the present context, the meaning of this item is not exclusively under the construct that underlies the depend subscale, but it still implies some degree of closeness.

Summing up, the results of Study 2 suggest that the Chilean version of the AASR is consistent with the threedimensional theoretical model that is intended to assess, provided that some overlapping between items 15 and 10 , and 15 and 5 is evidenced; as well as a cross-loading of item 5 on the close dimension, in addition to its original load on depend.

However, the reduced sample size of Study 2 in comparison to Study 1, for conducting a confirmatory factor analysis constitutes a limitation of this investigation that should be kept in mind when using the attachment scale in the local context.

\section{General Discussion}

In the present study we sought to adapt and provide evidence of construct validity of the AASR in the Chilean context. The results of the first study yield appropriate psychometric properties of the attachment dimensions in their internal consistency, temporal stability, and interrelations, although two items on the depend scale were a little problematic. Similarly, the attachment types resulted in the theoretically expected configurations, as well as the projected associations with convergent and divergent validity measures.

The results of two CFAs in Study 1, derived in a slight change in the wording of items 2 and 5 of the depend dimension, which were tested on a new sample in Study 2. This analysis initially yielded an unfit of the model until two correlated errors (which was probably due to similar 
meaning), as well as an item accounted for by two factors, were both included in the model.

The construct validity of the Chilean adaptation of the AASR showed the predicted convergent relationships of the model of the self (depend as well as close) with self-esteem, mate value and quality of relationships. In the case of self-esteem, it was crucial to replicate the positive association of this construct with close and depend, since RSE is a face valid measure of a positive self-concept (Collins \& Read, 1990). Similarly, the associations of self-esteem with close a bit higher in magnitude than self-esteem and depend, shows and appropriate differentiation of these two sub-dimensions of attachment; while the inverse relationship of RSE and anxiety with a similar moderate magnitude, suggests that the fear of being rejected or unloved was related to having a negative self-concept, confirming the strength of the AARS to tap into the model of the self and others. Mate value and perceived relationship quality, which are specific measures of success in attracting the opposite sex and having social skills, as well as experiencing positive romantic relationships, respectively, they all did show a positive association with close and depend and no correlation to anxiety. This suggests that in the area of mating, the model of the self is related to the perceived competence of the individual in romantic relationships, while the fear of rejection -prototypical of the model of others- is not important for this figure of self-efficiency in the mating realm (Collins \& Read, 1990, and see Collins, Ford, Guichard, \& Allard, 2006). An additional piece of construct validity on the model of the self was the lack of association of the dimensions of the AASR with the affect scales, indicative of a differentiation of the cognitive representations of the self and others which would be separated of the general affective approach to the world of the individual.

Additional convergent evidence of the pertinence of the AASR to the local context comes from the confirmation of positive associations of the model of others portrayed in the anxiety dimension, with jealousy, and different aspects of aggression; while the close and depend dimensions correlated inversely with these aspects of the self. Collins, Ford, Guichard, and Allard (2006) predicted elsewhere that adults with a negative model of others (high in anxiety, i.e. preoccupied) would experience intense levels of jealousy and conflict in relationships, which may be attributable to their lack of confidence in the love and intimacy of others. Indeed, in our results, jealousy reactivity (a continuous measure of how varying degrees of suspicion of a partner's interaction with the opposite sex may evoke jealousy) only correlates with the dimension of anxiety, and it is not associated with close and depend, which may be indicative of the lack of confidence in social acceptance and proximity of others to the self. On a similar way, the dimensions of aggression, which are highly related to a negative model of others, were associated in a positive direction with the dimension of anxiety, confirming the proposition that attachment patterns are schemas of how one "experiences, expresses and copes with distressing emotions" (Cooper et al., 1998, p. 1380). Indeed, it is precisely in terms of affective expressions of aggression where the negative model of others more strongly differentiates itself from the model of the self, with anger directly correlating with the dimension of anxiety. Nevertheless, in the cognitive basis of the attachment system, anxiety (or the negative view of others) was positively correlated with hostility, which is a persuasive cognitive scheme to perceive the world in a negative way, and others as having negative intentions towards the self. Divergently, the cognitive perception of others as hostile and having a negative attitude to the individual, showed a moderate and inverse association with the concept of the self, confirming the predicted configuration of aggression with respect to the attachment dimensions that constitute the AASR.

Across the two studies we found limitations related to the need of more optimal sampling that must be considered for future research: (a) we had a very reduced size of the test-retest subsample, and some of the criterion validity samples; (b) the sample size of the second study constitutes a limitation to large sample theory behind Structural Equation Modeling, and more specifically CFA (Byrne, 2006); (c) the gender distribution of our samples was highly biased towards women, with only close to $30 \%$ of men responding to the AASR in both studies. Thus, we cannot be certain that in a more gender equitable sample the results of the scale may remain similar to what we found.

In conclusion, we estimate that the Chilean version of the AASR has acceptable psychometric properties, allowing its use in the local context. This study also adds up evidence of construct validity to preexisting studies on the area. Nevertheless, we encourage further research aiming at replicate our findings, which may include larger and more gender equitable sample sizes (particularly for CFA); and other cognitive and affective constructs potentially related to attachment working models.

\section{References}

Ainsworth, M. D. S. (1979). Infant-mother attachment. American Psychologist, 34, 932-937. doi:10.1037/0003-066x.34.10.932

Bartholomew, K., \& Horowitz, L. M. (1991). Attachment styles among young adults: A test of a four-category model. Journal of Personality and Social Psychology, 61, 226-244. doi:10.1037//0022-3514.61.2.226

Bentler, P. M. (1990). Comparative fit indexes in structural models. Psychological Bulletin, 107, 238-246. doi:10.1037//00332909.107.2.238

Bowlby, J. (1989). Una base segura: aplicaciones clínicas de una teoría del apego. México, DF: Paidós. (Original work published 1979)

Brennan, K. A., \& Shaver, P. R. (1998). Attachment styles and personality disorders: Their connections to each other and to parental divorce, parental death, and perceptions of parental caregiving. Journal of Personality, 66, 835-878. doi:10.1111/1467-6494.00034 
Buss, A. H., \& Perry, M. P. (1992). The Aggression Questionnaire. Journal of Personality and Social Psychology, 63, 452-459.

Byrne, B. M. (2006). Structural equation modeling with EQS ( $2^{\text {nd }}$ ed.). London: Lawrence Erlbaum.

Collins, N. L. (1996). Working models of attachment: Implications for explanation, emotion, and behavior. Journal of Personality and Social Psychology, 71, 810-832. doi:10.1037//0022-3514.71.4.810

Collins, N. L., \& Feeney, B. C. (2004). Working models of attachment shape perceptions of social support: Evidence from experimental and observational studies. Journal of Personality and Social Psychology, 87, 363-383. doi:10.1037/00223514.87.3.363

Collins, N. L., \& Feeney, B. C. (2010). An attachment theoretical perspective on social support dynamics in couples: Normative processes and individual differences. In K. T. Sullivan \& J. Davila (Eds.), Support processes in intimate relationships (pp. 89-120). New York: Oxford University Press. doi:10.1093/ acprof:oso/9780195380170.003.0004

Collins, N. L., \& Feeney, B. C. (2013). Attachment and caregiving in adult close relationships: Normative processes and individual differences. Attachment \& Human Development, 15, 241-245. doi:10.1080/14616734.2013.782652

Collins, N. L., Ford, M. B., Guichard, A. C., \& Allard, L. M. (2006). Working models of attachment and attribution processes in intimate relationships. Personality and Social Psychology Bulletin, 32, 201-219. doi:10.1177/0146167205280907

Collins, N. L., Ford, M. B., Guichard, A. C., \& Feeney, B. C. (2006). Responding to need in intimate relationships: Normative processes and individual differences. In M. Mikulincer \& G. Goodman (Eds.), Dynamics of romantic love: Attachment, caregiving, and sex (pp. 149-189). New York: The Guilford Press.

Collins, N. L., \& Read, S. J. (1990). Adult attachment, working models, and relationship quality in dating couples. Journal of Personality and Social Psychology, 58, 644-663. doi:10.1037//0022-3514.58.4.644

Cooper, M. L., Shaver, P. R., \& Collins, N. L. (1998). Attachment styles, emotion regulation, and adjustment in adolescence. Journal of Personality and Social Psychology, 74, 1380-1397. doi:10.1037//0022-3514.74.5.1380

Dijkstra, P., Barelds, D. P., \& Groothof, H. A. (2010). An inventory and update of jealousy-evoking partner behaviours in modern society. Clinical Psychology and Psychotherapy, 17, 329-345. doi:10.1002/cpp.668

Dufey, M., \& Fernández, A. M. (2012). Validez y confiabilidad del Positive Affect and Negative Affect Schedule (PANAS) en Chile. Revista Iberoamericana de Diagnóstico y Evaluación Psicológica, 34, 157-173.

Feeney, B. C., \& Collins, N. L. (2001). Predictors of caregiving in adult intimate relationships: An attachment theoretical perspective. Journal of Personality and Social Psychology, 80, 972-994. doi:10.1037/0022-3514.80.6.972

Fernández, A. M., Pavez, P., \& Dufey, M. (in press). Evaluación chilena del inventario de comportamientos de la pareja que provocan celos. Revista de Psicología.

Fernández, A. M., Muñoz-Reyes, J. A., Dufey, M., Buccioni, G., \& Cid, V. (in press). Adaptación del Cuestionario de Componentes del Valor de Pareja al contexto chileno. Revista Iberoamericana de Diagnóstico y Evaluación Psicológica.

Figueroa Rey, P., Ramírez Troncoso, C. G., \& Santis Doyhamboure, M. (2005). Adaptación y validación del Buss-Perry aggression questionnaire a la población adolescente, adulta y adulta mayor del gran Santiago (Unpublished undergraduate thesis, Universidad Diego Portales, Santiago, Chile).

Fisher, M., Cox, A., Bennett, S., \& Gavric, D. (2008). Components of self-perceived mate value. Journal of Social, Evolution \& Cultural Psychology, 2, 156-168. doi:10.1037/ h0099347

Fletcher, G. J., Simpson, J. A., \& Thomas, G. (2000). The measurement of perceived relationship quality components: A confirmatory factor analytic approach. Personality and Social Psychology Bulletin, 26, 340-354. doi:10.1177/0146167200265007

Fletcher, G. J., Simpson, J. A., Thomas, G., \& Giles, L. (1999). Ideals in intimate relationships. Journal of Personality and Social Psychology, 76, 72-89. doi:10.1037/0022-3514.76.1.72

Ford, M. B., \& Collins, N. L. (2010). Self-esteem moderates neuroendocrine and psychological responses to interpersonal rejection. Journal of Personality and Social Psychology, 98, 405-419. doi:10.1037/a0017345

Fraley, R. C., Waller, N. G., \& Brennan, K. A. (2000). An item response theory analysis of self-report measures of adult attachment. Journal of Personality and Social Psychology, 78, 350-365. doi:10.1037/0022-3514.78.2.350

Guzmán, M., \& Contreras, P. (2012). Estilos de apego en relaciones de pareja y su asociación con la satisfacción marital. Psykhe, 21, 69-82. doi:10.4067/S0718-22282012000100005

Hazan, C., \& Shaver, P. (1987). Romantic love conceptualized as an attachment process. Journal of Personality and Social Psychology, 52, 511-524. doi:10.1037/0022-3514.52.3.511

Hazan, C., \& Shaver, P. R. (1994). Deeper into attachment theory. Psychological Inquiry, 5, 68-79. doi:10.1207/ s15327965pli0501 15

Hu, L., \& Bentler, P. M. (1999). Cutoff criteria for fit indexes in covariance structure analysis: Conventional criteria versus new alternatives. Structual Equation Modeling, 6, 1-55. doi:10.1080/10705519909540118

Mikulincer, M., \& Shaver, P. R. (2007). Attachment, grouprelated processes, and psychotherapy. International Journal of Group Psychotherapy, 57, 233-245. doi:10.1521/ ijgp.2007.57.2.233

Mota, C. P., \& Matos, P. M. (2009). Attachment, conflict and self-esteem in adolescents from intact and divorced families. Psicologia: Reflexão e Crítica, 22, 344-352. doi:10.1590/ S0102-79722009000300004

Paiva, C. A., \& Figueiredo, B. (2010). Study of validation of the Portuguese version of the inventory Experiences in Close Relationships. Interpersona, 4, 237-270. doi:10.5964/ijpr. v4i2.51

Rojas-Barahona, C. A., Zegers, B., \& Förster, C. E. (2009). La escala de Autoestima de Rosenberg: validación para Chile en una muestra de jóvenes adultos, adultos y adultos mayores. Revista Medica de Chile, 137, 791-800. doi:10.4067/S003498872009000600009

Rosenberg, M. (1965). Society and the adolescent self-image. Princeton, NJ: Princeton University Press.

Satorra, A., \& Bentler, P. M. (1988). Scaling corrections for statistics in covariance structure analysis. Los Angeles, CA: Department of Psychology, University of California.

Schmitt, D. P., Alcalay, L., Allik, J., Angleitner, A., Ault, L., Austers, I., ...Zupanèiè, A. (2004). Patterns and universals of mate poaching across 53 nations: The effects of sex, culture, and personality on romantically attracting another person's partner. Journal of Personality and Social Psychology, 86, 560-584. doi:10.1037/0022-3514.86.4.560 
Fernández, A. M. \& Dufey, M. (2015). Adaptation of Collins' Revised Adult Attachment Dimensional Scale to the Chilean Context.

Schumacker, R. E., \& Lomax, R. G. (2004). A beginner's guide to structural equation modeling ( $2^{\text {nd }}$ ed.). Mahwah, NJ: Lawrence Erlbaum.

Shaver, P., Collins, N. L., \& Clark, C. (1996). Attachment theory and internal working models of self and relationship partners In G. Fletcher \& J. Fitness (Eds.), Knowledge structures in close relationships: A social psychological approach (pp. 25-61). Hillsdale, NJ: Erlbaum.

Triandis, H., \& Berry, J. W. (Eds.). (1980). Handbook of crosscultural psychology. Boston, MA: Allyn \& Bacon. doi:10.1 080/10705511.2011.607726

Verissimo, M., Fernandes, C., Santos, A., Peceguina, I., Vaughn, B., \& Bost, K. (2011). The relation between quality of attachment and the development of social competence in preschool children. Psicologia: Reflexão e Crítica, 24, 292299. doi:10.1590/S0102-79722011000200010

Watson, D., Clark, L. A., \& Tellegen, A. (1988). Development and validation of brief measures of positive and negative affect: The PANAS scales. Journal of Personality and Social Psychology, 54, 1063-1070. doi:10.1037/00223514.54.6.1063

\section{Appendix}

\section{Spanish Version of the Collin's Adult Attachment Scale Revised*}

Las preguntas que vienen a continuación apuntan a cómo se siente Ud. generalmente en las relaciones cercanas importantes de su vida. Piense en sus relaciones pasadas y presentes con personas que han sido especialmente importantes para Ud., tales como miembros de su familia, parejas románticas y amigos cercanos. Responda a cada afirmación en términos de cómo se siente Ud. generalmente en estas relaciones.

Por favor utilice la escala de más abajo colocando un número entre 1 y 5 en el espacio que se encuentra a la derecha de cada afirmación.

$\begin{array}{cc}\text { Para nada es } & \text { Muy característico } \\ \text { característico de mí } & \text { de mí }\end{array}$

1) Encuentro que me es relativamente fácil acercarme a la gente.

I find it relatively easy to get close to people.

2) Me resulta difícil apoyarme en otras personas

I find it difficult to allow myself to depend on others.

3) A menudo me preocupa que los otros no me amen realmente.

I often worry that other people don't really love me.

4) Encuentro que los otros no se acercan a mi tanto como yo quisiera.

I find that others are reluctant to get as close as I would like.

5) Me siento cómodo apoyándome en otras personas.

I am comfortable depending on others.

6) No me preocupa que la gente se acerque demasiado a mí

I don't worry about people getting too close to me.

7) Encuentro que las personas nunca están ahí cuando las necesitas.

I find that people are never there when you need them.

8) Me siento algo incómodo estando cerca de otros.

I am somewhat uncomfortable being close to others. 
9) A menudo me preocupa que los otros no quieran quedarse conmigo.

I often worry that other people won't want to stay with me.

10) Cuando muestro mis sentimientos por otros me asusta que no sientan lo mismo por mi.

When I show my feelings for others, I'm afraid they will not feel the same about me.

11) A menudo me pregunto si realmente le importo a las otras personas.

I often wonder whether other people really care about me.

12) Me siento cómodo desarrollando relaciones cercanas con otros.

I am comfortable developing close relationships with others.

13) Me siento incómodo cuando cualquier persona se vuelve demasiado cercana emocionalmente a mí. I am uncomfortable when anyone gets too emotionally close to me.

14) Sé que las personas estarán ahí cuando las necesite.

I know that people will be there when I need them.

15) Quiero acercarme a la gente pero me preocupa ser herido.

I want to get close to people, but I worry about being hurt.

16) Encuentro difícil confiar completamente en otros.

I find it difficult to trust others completely.

17) A menudo las personas quieren que sea más cercano emocionalmente de lo que a mí me acomoda.

People often want me to be emotionally closer than I feel comfortable being.

18) No estoy seguro de que siempre podré contar con las personas cuando las necesite.

I am not sure that I can always depend on people to be there when I need them.

Note. *The original items in English from Collins (1996) are in italics below each of the Spanish statements. 